\title{
KARAKTERISTIK GELATIN BERBAHAN BAKU TULANG IKAN CAKALANG (Katsuwonus pelamis) DENGAN MENGGUNAKAN JENIS ASAM YANG BERBEDA
}

Characteristics of gelatin made from skipjack fish (Katsuwonus pelamis) using different types of acids

\author{
Farida $^{{ }^{*}}$, Kobajashi T. Isamu ${ }^{1}$, Nur Illiyyin Akib² \\ 1Jurusan Teknologi Hasil Perikanan, Fakultas Perikanan dan Ilmu Kelautan Universitas Halu Oleo, Kendari, \\ Sulawesi Tenggara, Indonesia \\ 2Jurusan Farmasi, Fakultas Farmasi Universitas Halu Oleo, Kendari, Sulawesi Tenggara, Indonesia \\ *Email korespondensi: faridathp015@gmail.com (Telp: +6285298580147) \\ Diterima: 9 Januari/ Disetujui 10 Maret 2020
}

Cara sitasi: Farida, Isamu KT, Akib NI. 2020. Karakteristik gelatin berbahan baku tulang ikan cakalang (Katsuwonus pelamis) dengan menggunakan jenis asam yang berbeda. Jurnal Fish Protech. 3(1):79-86.

\section{ABSTRACT}

The aim of this study was to determine the gelatin processing technique using different types of acids and the effect of the use of acid as an extracting agent on the gelatin quality of skipjack fish bones. This study used a Completely Randomized Design (CRD) consisting of 3 treatments, namely A1 (immersion with $4 \% \mathrm{HCl}$ ), A2 (immersion with $4 \%$ $\mathrm{CH}_{3} \mathrm{COOH}$ ) and $\mathrm{A} 3$ (immersion with $4 \% \mathrm{H}_{2} \mathrm{SO}_{4}$ ). Each treatment was carried out 3 times, so that the number of experimental units was 9 units. Data from observations were analyzed using ANOVA (Analysis of Variance) at a level of $95 \%$, if there was a significant difference $(p<0.05)$, further tests were carried out with the DMRT (Duncan Multiple Range Test) test at a 95\% significance level. The results obtained showed that the characteristics of gelatin made from skipjack fish bones by using a different type of acid did not have a significant effect on sensory values which included color and aroma. The best results for sensory assessment of the immersion using sulfuric acid were 6.2 and the aroma sensory test with immersion using hydrochloric acid was 5.4. The results of gelatin proximate showed that the water content ranged from $3.99 \%-13.32 \%$ ash content $2.27-3.19 \%$ protein content $27.08 \%-35.42 \%$ and $p H 2.93 \%-4.81 \%$.

Keywords: gelatin, skipjack fish, hydrochloric acid, sulfuric acid and acetic acid

\section{ABSTRAK}

Tujuan penelitian ini adalah untuk mengetahui teknik pengolahan gelatin dengan menggunakan jenis asam yang berbeda dan pengaruh penggunaan asam sebagai bahan pengestrak terhadap kualitas gelatin tulang ikan cakalang. Penelitian ini menggunakan Rancangan Acak Lengkap (RAL) yang terdiri dari 3 perlakuan yaitu A1 (perendaman dengan $\mathrm{HCl} 4 \%$ ), $\mathrm{A} 2$ (perendaman dengan $\mathrm{CH}_{3} \mathrm{COOH} 4 \%$ ) dan A3 (perendaman dengan $\mathrm{H}_{2} \mathrm{SO}_{4} 4 \%$ ). Masing-masing perlakuan dilakukan 3 kali ulangan, sehingga diperoleh jumlah satuan percobaan sebanyak 9 unit. Data hasil pengamatan dianalisa menggunakan ANOVA (Analysis of Variance) pada taraf $95 \%$, apabila terdapat beda nyata $(p<0,05)$ maka dilakukan uji lanjut dengan uji DMRT (Duncan Multiple Range Test) pada taraf nyata 95\%. Hasil penelitian yang diperoleh menunjukkan bahwa karakteristik gelatin berbahan baku tulang ikan cakalang dengan menggunakan jenis asam yang berbeda tidak memberikan pengaruh nyata terhadap nilai sensori yang meliputi warna dan aroma. Hasil terbaik untuk penilaian sensori terhadap pada perendaman menggunakan asam sulfat yaitu 6,2 dan uji sensori aroma dengan perendaman menggunakan asam klorida yaitu 5,4 . Hasil proksimat gelatin menunjukkan kadar air berkisar antara 3,99\%-13,32\% kadar abu 2,27-3,19\% kadar protein 27,08\%-35,42\% dan $\mathrm{pH} 2,93 \%-4,81 \%$.

Kata kunci: gelatin, tulang ikan, $\mathrm{HCl}, \mathrm{H}_{2} \mathrm{SO}_{4}, \mathrm{CH}_{3} \mathrm{COOH}$ 


\section{PENDAHULUAN}

Tuna, cakalang, tongkol dan ikan lainnya merupakan komoditas utama dalam perikanan tangkap di Indonesia yang terus mengalami pertumbuhan. Pada tahun 2013 produksi perikanan tangkap Indonesia mencapai 5.707.013 ton dan pada tahun 2014 produksi perikanan tangkap Indonesia meningkat menjadi 6.037.645 ton. Sulawesi Tenggara merupakan salah satu provinsi yang mengalami pertumbuhan dalam produksi perikanan tangkap, tahun 2013 produksi perikanan tangkap Sulawesi Tenggara mencapai 127.777 ton dan pada tahun 2014 meningkat menjadi 153.519 ton (Kelautan dan Perikanan 2015).

Gigenetika (2012) dalam Alamsyah et al. (2014), menambahkan bahwa ikan cakalang merupakan salah satu sumber daya perikanan pelagis yang banyak dijadikan objek dalam usaha perikanan tangkap. Spesies ikan ini digunakan sebagai bahan baku oleh berbagai jenis industri pengolahan seperti cakalang fufu, ikan kayu, ikan kaleng, abon cakalang, dan masih banyak lagi. Ikan cakalang menjadi komoditi ekspor baik dalam bentuk segar, beku, maupun olahan.

Ikan cakalang mempunyai tulang 8,1-11,1\% (Kizevetter 1993 dalam Garwan 2009). Sekitar 30\% dari tulang disusun oleh komponen-komponen organik, dan diantaranya adalah kolagen (Chi et al.,2001). Menurut Marsaid dan Atmaja (2011) proporsi tulang ikan terhadap tubuh ikan mencapai $12,4 \%$. Limbah padat berupa tulang dari hasil pengolahan diperkirakan sebanyak 17.460 ton.

Apabila limbah-limbah tersebut tidak dimanfaatkan dengan baik, maka dapat mencemari lingkungan yang dapat mengganggu kesehatan bagi masyarakat di sekitarnya. Diketahui limbah-limbah tersebut baru diolah menjadi tepung ikan sebagai pakan ternak dan dengan memanfaatkan limbah tulang ikan menjadi gelatin sebagai bahan tambahan makan (food additive) yang bernilai ekonomis tinggi dapat menjadi solusi dari permasalahan limbah dari industri pengolahan perikanan.

Pemanfaatan tulang ikan cakalang sebagai alternatif pembuatan gelatin halal merupakan usaha pengurangan limbah industri pada pengolahan ikan. Alternatif pembuatan gelatin dari tulang ikan cakalang dilakukan agar tercipta industri perikanan yang nir limbah. Pemanfaatan gelatin tulang ikan selain menciptakan suasana ramah lingkungan juga menghasilkan produk yang bernilai tambah.

Penelitian Mulyani et al. (2012), pada tulang ikan kakap menggunakan larutan asam klorida 3\%, larutan asam sulfat $3 \%$ dan larutan asam fosfat 3\% diperoleh rendemenen gelatin berturut turut $\pm 14 \%$; $\pm 11,5 \%$ dan $\pm 9,9 \%$. Penelitian tentang ekstraksi gelatin dari tuang ikan cakalang dari berbagai variasi jenis asam belum pernah dilakukan.Jika dilihat dari potensinya di Sulawesi Tenggara, ikan cakalang merupakan sumber gelatin dari perairan yang sangat melimpah keberadaannya dan memiliki potensi besar untuk dijadikan sumber gelatin halal.

Penelitian ini akan dilakukan pembuatan gelatin dari tulang ikan cakalang dengan variasi larutan asam sebagai bahan pengestraksi selanjutnya gelatin yang diperoleh akan dikarakterisasi sehingga diketahui pengaruh penggunaan jenis asam yang berbeda terhadap kualitas gelatin yang dihasilkan.

\section{METODE PENELITIAN}

\section{Alat dan Bahan}

Alat yang digunakan dalam penelitian ini terdiri dari hot plate, waterbath, oven, desikator (duran), gelas beaker (pyrex), gelas ukur (pyrex), cawan petri (pyrex), kertas saring whatman no.4, ayakan 100 mesh, pisau (lion star), timbangan analitik (matrix), blender (miyako), kertas $\mathrm{pH}$, alat pengujian viskositsas, alat pengujian $\mathrm{pH}$, dan alat pengujian proksimat.

Bahan baku yang digunakan pada penelitian ini adalah tulang ikan cakalang, air, $\mathrm{CH}_{3} \mathrm{COOH}$ /asam asetat (fluka), $\mathrm{HCl} /$ asam klorida (merck), $\mathrm{H}_{2} \mathrm{SO}_{4} /$ asam sulfat (merck), aquades. 


\section{Rancangan Penelitian}

Penelitian ini menggunakan Rancangan Acak Lengkap (RAL) yang terdiri dari 3 perlakuan yaitu $A 1$ (perendaman dengan $\mathrm{HCl} 4 \%$ ), A2 (perendaman dengan $\mathrm{CH}_{3} \mathrm{COOH} 4 \%$ ) dan $\mathrm{A} 3$ (perendaman dengan $\mathrm{H}_{2} \mathrm{SO} 44 \%$ ). Masing-masing perlakuan dilakukan 3 kali ulangan, sehingga diperoleh jumlah satuan percobaan sebanyak 9 unit.

\section{Prosedur Penelitian}

\section{Preparasi Sampel}

Sampel tulang ikan cakalang diperoleh dari PT OME, Kec. Abeli, Kota Kendari, Sulawesi Tenggara. Tulang ikan ditempatkan dalam wadah, untuk dibawa ke laboratorium untuk dilakukan pencucian, pembersihan dari sisa-sisa daging yang masih menempel dan penimbangan.

\section{Tahap Degreasing(penghilangan Lemak)}

Tahap degreasing dilakukan dengan pemasakan tulang ikan dalam air pada suhu $70^{\circ} \mathrm{C}$ selama 30 menit dengan rasio $1: 2$. Selanju tnya dilakukan proses pembersihan yaitu pencucian menggunakan air. Kemudian dilakukan pengecilan ukuran tulang ikan menjadi 3-5 cm menggunakan pisau dan dikeringkan menggunakan sinar matahari.

\section{Tahap Demineralisasi (Penghilangan Kalsium)}

Tulang ikan cakalang yang telah dikecilkan ukurannya selanjutnya dimasukkan ke dalam gelas kimia yang berisi larutan asam asetat, asam klorida, dan asam sulfat dengan konsentrasi $4 \%$. Kemudian direndam selama 2 hari atau 48 jam dengan rasio 1:7 dan larutan asam diganti setiap 24 jam sehingga dihasilkan tulang lunak yang disebut ossein. Selanjutnya ossein dinetralkan $\mathrm{pH}$ nya menggunakan kertas $\mathrm{pH}$ sehingga mendekati $\mathrm{pH}$ netral dengan cara mengaliri osein dengan air mengalir selama \pm 1 jam. Setelah mendekati $\mathrm{pH}$ netral ossein tersebut dibilas.

\section{Tahap Ekstraksi}

Ossein sebanyak 150 gram diekstraksi menggunakan aquades dengan cara dimasukkan kedalam waterbath pada suhu $80^{\circ} \mathrm{C}$ selama $7 \mathrm{jam}$ dengan perbandingan 1:3. saat proses berlangsung dilakukan pengambilan minyak yang berwarna coklat. Kemudian ekstrak yang dihasilkan di saring menggunakan kertas saring whatman No.4. sehingga menghasilkan filtrat.

\section{Tahap Drying}

Proses pengeringan dengan cara ekstrak dituang kedalam cawan petri dan dimasukkan kedalam oven pada suhu $65^{\circ} \mathrm{C}$ selama 48 jam hingga diperoleh ekstrak kering. Selanjutnya ekstrak kering dimasukkan ke dalam desikator yang didinginkan, digerus, diblender dan diayak menggunakan ayakan 100 mesh hingga halus seperti bubuk. Bubuk gelatin yang diperoleh selanjutnya dilakukan analisis kualitas gelatin.

\section{Variabel Pengamatan}

Variabel pengamatan pada penelitian ini terdiri dari uji sensorik yang meliputi : Aroma dan Warna (SNI NO. 06-3735a). Analisis komposisi proksimat gelatin berbahan baku tulang ikan cakalang dengan menggunakan jenis asam yang berbeda meliputi kadar air (AOAC 1995), kadar abu (AOAC 2005), kadar protein (Fahmuddin et al., 2005), pH (Rahayu, 2008), rendemen (AOAC 1995).

\section{Analisis Data}

Analisis data yang digunakan dalam penelitian ini adalah dengan menggunakan sidik ragam Analisis of Varian (ANOVA) dan jika hasil analisis terdapat perbedaan nyata, maka dilanjutkan dengan uji lanjut Duncan Multiple Range Test (DMRT) pada taraf kepercayaan $95 \%(a=0,05)$. 


\section{Uji sensori}

\section{HASIL DAN PEMBAHASAN}

Hasil rerata penilaian uji sensori tiap perlakuan terhadap parameter warna dan aroma disajikan pada Tabel 1. Tabel 1. Rata-rata uji sensori gelatin

\begin{tabular}{ccccc}
\hline \multirow{2}{*}{ Perlakuan } & \multicolumn{4}{c}{ Parameter } \\
\cline { 2 - 5 } & Warna $\pm \mathrm{SD}$ & Kategori & Aroma $\pm \mathrm{SD}$ & Kategori \\
\hline $\mathrm{CH}_{3} \mathrm{COOH}^{*}$ & $6,12 \pm 0,04$ & Putih & $5,27 \pm 0,12$ & Kurang harum spesifikikan \\
$\mathrm{HCl}^{*}$ & $6,08 \pm 0,04$ & Puth Kekuningan & $5,33 \pm 0,06$ & Kurang harum spesifikikan \\
$\mathrm{H}_{2} \mathrm{SO}_{4}{ }^{*}$ & $6,16 \pm 0,11$ & Puth Cerah & $5,26 \pm 0,12$ & Kurang harum spesifikikan \\
\hline
\end{tabular}

Keterangan : * perendaman selama 48 jam dengan konsentrasi $4 \%$. Tabel 2.

Hasil analisis kimia gelatin meliputi kadar air, kadar abu, kadar protein dan nilai pH disajikan pada

Tabel 2. Analisis kimia gelatin

$$
\text { Perlakuan }
$$

\begin{tabular}{lrrrc} 
Parameter & $\mathrm{CH}_{3} \mathrm{COOH}^{*}$ & $\mathrm{HCl}^{*}$ & $\mathrm{H}_{2} \mathrm{SO}_{4}{ }^{*}$ & $\mathrm{SNI} 1995$ \\
\hline Kadar Air \% & 3,99 & 6,82 & 13,32 & Maksimum 16\% \\
Kadar Abu\% & 2,84 & 3,19 & 2,27 & Maksimum 3,2\% \\
Protein \% & 46,88 & 35,42 & 27,08 & $87,25 \%$ \\
pH\% & 4,81 & 3,34 & 2,93 & $3,8-6,0$ \\
\hline
\end{tabular}

Keterangan: * perendaman selama 48 jam dengan konsentrasi larutan $4 \%$.

Data hasil penelitian analisis total rendemen disajikan pada Tabel 3.

Tabel 3. Hasil analisis total rendemen gelatin

\begin{tabular}{clll}
\hline Perlakuan & $\begin{array}{l}\text { Berat } \\
\text { Baku }(\mathrm{g})\end{array}$ & Bahan Berat Sampel (g) & Total Rendemen \% \\
\hline $\mathrm{CH}_{3} \mathrm{COOH}^{*}$ & 600 & 6,2516 & 1,04 \\
$\mathrm{HCl}^{*}$ & 600 & 7,3150 & 1,21 \\
$\mathrm{H}_{2} \mathrm{SO}_{4}{ }^{*}$ & 600 & 11,0142 & 83.1 \\
\hline
\end{tabular}

Keterangan : * perendaman dengan konsentrasi $4 \%$.

\section{Uji Organoleptik/Sensori}

Warna

Warna gelatin yang dihasilkan pada penelitian ini sesuai standar SNI No. 06-3735-1995 dengan kriteria tidak berwarna sampai kekuningan kesesuaian ini diduga dipengaruhi oleh kesegaran bahan baku pembuatan gelatin. Hal ini sesuai pernyataan Gunawan et al. (2017) bahwa kecerahan gelatin ditentukan oleh bahan baku dan proses pembuatan gelatin. Gelatin pada umumnya diharapkan berwarna puth karena gelatin yang bermutu tinggi biasanya tidak berwarna, selain itu gelatin yang berwarna semakin putih semakin baik sehingga aplikasi bisa lebih luas.

Menurut Wiraatmaja (2006) warna putih kekuningan gelatin dikarenakan proses pengeringan juga dipengaruhi oleh kesegaran bahan baku. Selain itu juga warna gelatin berkaitan dengan tingkat efektifitas proses pretreatment yaitu pelepasan pigmen selama proses perendaman dengan larutan atau senyawa yang digunakan (Alhana et al., 2015). Meskipun proses perendaman dengan larutan mampu 
menarik pigmen dari bahan baku akan tetapi secara statistik perendaman dengan menggunakan jenis asam yang berbeda tidak memberikan pengaruh secara signifikan terhadap karakteristik warna gelatin tulang ikan cakalang yang dihasilkan.

\section{Aroma}

Menurut Nurmilah dan Siti (2018) aroma yang dihasilkan dari gelatin tulang ikan berasal dari komponen senyawa folatil yang berasal dari bahan baku dan terperangkap selama proses pembuatan gelatin sehingga Hal ini dikarenakan aroma dari bahan baku yang digunakan yaitu tulang ikan cakalang tidak memiliki aroma khas ikan sehingga jenis asam yang diberikan mempengaruhi secara signifikan aroma gelatin ikan yang dihasilkan. Hal ini juga didukung oleh penelitian Pratama et al. (2013) menunjukkan bahwa pada ikan terkandung senyawa folatil yang pada umumnya terdiri dari beberapa komponen penyusun diantaranya adalah aldehid, alkohol, keton dan hidrokarbon.

\section{Uji Kimia}

\section{Kadar Air}

Menurut Santoso et al. (2015) kadar air yang terkandung pada gelatin tulang ikan akan mempengaruhi daya tahan gelatin itu sendiri terhadap serangan mikroba. Kadar air pada penelitian ini tidak memenuhi standar SNI 06-3735 (1995) yaitu 16\%. Hal ini diduga karena ikatan yang terbentuk antara molekul gelatin dengan air masih lemah, sehingga jumlah air yang terperangkap di dalam struktur molekul gelatin sedikit. Hal ini didukung oleh pernyataan Jones (1977), bahwa semakin rendah konsentrasi gelatin dalam larutan maka ikatan antar molekulnya juga semakin lemah, sehingga jumlah air yang terperangkap dalam molekul gelatin sedikit. Peneliti sebelumnya pengaruh variasi jenis asam terhadap rendemen gelatin dari tulang ikan cakalang dengan perendaman asam asetat $5 \%$ yakni $3,72 \%$.

Rendahnya kadar air gelatin pada perendaman asam asetat diduga karena kolagen yang terisolasi lebih banyak dibandingkan gelatin dengan perendaman asam klorida dan asam sulfat. Hal ini diduga karena asam asetat merupakan asam kuat dibandingkan asam klorida dan asam sulfat, sehingga proses hidrolisis lebih optimal, yang menyebakan kadar air pada gelatin tulang ikan cakalang dengan perendaman asam sulfat lebih rendah. Hal ini sesuai dengan peryataan (Wicaksono, 2017), bahwa asam dapat menyebabkan proses hidrolisis karena dapat mempercepat proses terpecahnya kadar air menjadi $\mathrm{H}^{+}$dan $\mathrm{OH}^{-}$sehingga kadar air pada tulang akan berkurang.

Perbedaan nilai kadar air pada setiap perlakuan dipengaruhi oleh banyaknya kolagen yang terbentuk pada gelatin, maka menyebabkan ikatan hidrogen yang berasal dari non kolagen akan berikatan dengan molekul air, sehingga pada proses pengeringan akan menguap bersamaan dengan air yang menyebabkan kadar air menurun. Menurut Ulfah (2011) hidrogen bersifat polar, sifat tersebut yang akan menyebabkan banyaknya air yang menguap pada saat pengeringan dalam oven sehingga kadar air akan lebih rendah.

\section{Kadar abu}

Nilai kadar abu pada penelitian ini masih memenuhi standar SNI 06-3735 (1995) dan standar GMIA (2012), sedangkan pada penelitian lqbal et al. (2015), kadar abu sangat jauh berbeda dengan hasil yang didapat maupun dengan standar yang ada yaitu $12,1 \%$. Kadar abu adalah satu parameter yang digunakan untuk melihat kualitas dan tingkat keberhasilan dari proses ekstraksi pada gelatin.

Penelitian sebelumnya kadar abu penelitian pada gelatin tulang ikan kaci-kaci dengan konsentrasi 3\% asam asetat menghasilkan kadar abu sebesar 1,96\% Tazwir (2007), dan pada gelatin tulang ikan kakap dengan konsentrasi 3\% menghasilkan kadar abu sebesar 0,4\% (Trilaksani et al., 2012) dan pada gelatin tulang ikan tuna dengan konsentrasi $3 \%$ menghasilkan kadar abu sebesar 8,02\% (Panjaitan, 2017).

\section{Kadar protein}

Menurut Junianto dan Kiki (2006) kolagen dapat mengalami penyusutan jika dipanaskan diatas suhu penyusutan. Kondisi suhu ini akan memperpendek serat kolagen sebesar sepertiga atau seperempat dari panjang asalnya, proses penyusutan kolagen menyebabkan struktur kolagen pecah menjadi lilitan 
acak yang larut dalam air dan disebut dengan gelatin.

Suhu penyusutan dimulai dari suhu $35^{\circ} \mathrm{C}$.

Gelatin sebagai salah satu jenis protein konversi yang dihasilkan melalui proses hidrolisis kolagen. Uji kadar protein menunjukkan seberapa besar kandungan protein yang terdapat dalam suatu bahan pangan (Ulfah, 2011). Kadar protein tertinggi pada penelitian ini diperoleh pada gelatin dengan perendaman asam asetat sedangkan terendah diperolah pada gelatin dengan perendaman asam sulfat. Tingginya protein pada gelatin dengan perendaman asam asetat diduga karena asam asetat mampu menghidrolisis kolagen dengan sempurna (Sasmitaloka et al., 2017). Hal ini diduga bahwa asam asetat mampu menguraikan serat kolagen lebih banyak dan cepat tanpa mempengaruhi kualitas gelatin yang dihasilkan serta mengubah serat kolagen tripel heliks menjadi rantai tunggal. Nilai kadar protein pada penelitian ini diperoleh pada gelatin dengan perendaman asam asetat karena memiliki nilai tertinggi. Gelatin dengan kadar protein tinggi diharapkan dapat memberikan tambahan zat gizi terhadap produk pangan olahan selanjutnya.

\section{Derajat keasaman $\mathrm{pH}$}

Perbedaan nilai $\mathrm{pH}$ disebabkan karena perbedaan jenis asam yang digunakan pada saat ekstraksi.Nilai pH tertinggi diperoleh dari gelatin yang diekstraksi menggunakan asam asetat dan asam sulfat sedangkan terendah diperoleh dari ekstraksi dari asam klorida.

Rendahnya nilai $\mathrm{pH}$ gelatin yang disebabkan Karena asam asetat merupakan asam kuat dibandingkan asam klorida dan asam sulfat. Dimana hal ini diduga pada saat proses perendaman terjadi pembengkakan pada kolagen, dikarenakan sisa larutan yang tidak bereaksi terserap dalam kolagen dan terperangkap pada jaringan kolagen, sehingga pada saat pencucian tidak ikut tercuci, dan terekstraksi pada saat ekstraksi sehingga mempengaruhi nilai $\mathrm{pH}$ yang dihasilkan. Hal ini diperkuat oleh Sartika (2009) bahwa nilai $\mathrm{pH}$ gelatin dipengaruhi oleh proses pencucian setelah direndam dalam larutan asam.

\section{Rendemen}

Dari Tabel 3. Terlihat rendemen yang tertinggi dapat dilihat bahwa rendemen tertinggi terdapat pada perendaman asam sulfat yaitu sebesar 1,83\%, sedangkan rendemen yang terendah terdapat pada perendaman asam asetat yaitu sebesar 1,04\%. Hal ini diduga karena jumlah ion $\mathrm{H}^{+}$yang menghidrolisis kolagen tulang ikan cakalang berbeda-beda tergantung jenis asam yang digunakan, semakin banyak ion $\mathrm{H}^{+}$semakin meningkat jumlah rendemen. Hal ini disebabkan oleh adanya proses pengikatan mineral kalsium dalam tulang ikan cakalang sehingga menyebabkan terbebasnya kolagen dalam tulang ikan cakalang tersebut.

Rendemen terendah dihasilkan dengan perendaman asam asetat yaitu 1,04\%. Hal ini disebabkan kerena konsentrasi asam asetat yang digunakan lebih sedikit. Hal ini diduga semakin tinggi konsentrasi asam asetat, maka konsentrasi ion $\mathrm{H}^{+}$ juga meningkat sehingga proses hidrolisis menjadi lebih cepat. Nilai rendemen gelatin pada penelitian ini lebih rendah dari rendemen gelatin penelitian Azara (2017) dimana hasil penelitiannya nilai rendemen yang dihasilkan berkisar antara 4,29\%-6,99\% dengan lama perendaman 18 dan 24 jam.

\section{KESIMPULAN}

Simpulan dalam penelitian ini yaitu sebagai berikut :

1. Gelatin tulang ikan cakalang diperoleh hasil terbaik uji sensori warna dengan perendaman menggunakan asam sulfat yaitu 6,2 dan uji sensori aroma dengan perendaman menggunakan asam klorida yaitu 5,4 . Nilai kadar air $13,32 \%$, kadar abu $3,19 \%$, kadar protein $35,42 \%, \mathrm{pH} 4,81 \%$ dan total rendemen yang diperoleh $1,83 \%$.

2. Penggunaan jenis asam yang berebeda tidak berpengaruh nyata terhadap aroma, warna, kadar air, kadar abu, kadar protein dan $\mathrm{pH}$ gelatin tulang ikan cakalang. 


\section{DAFTAR PUSTAKA}

AOAC. 1995. Official Methods of Analysis of The Association of Official Analytical

Association of Off Analytical Chemist [AOAC]. 2005. Official Methods of Analysis (18 Edn). Association of Official Analytical Chemist Inc. Mayland. USA.

Alhana, Suptijah P, Tarman K. 2015. Extrakction and Characterization ofCollagen from Sea Cucumbar Flesh.Jurnal Pengolahan Hasil Perikanan Indonesia. 18(2): 150-161.

Alamsyah, A., Peranginangin, Y., dan Nurhadi, G. (2014). Learning Organization using Conversational Social Network For Social Customer Relationship Management Effort.2nd International Conference and Seminar on Learning Organization.

Azara, R. 2017. Pembuatan dan Analisis Sifat Fisikokimia Gelatin dari Limbah Kulit Ikan Kerapu (Ephinephelus sp.). Universitas Muhamadiyah Sidoarjo, Sidoarjo. Jurnal Media Teknologi Hasil Pertanian, Vol. 11, No. 1.

Chi H.L., Anuj S dan yungyung I. 2001. Review Biomedical Application of Collagen. International Journal of Pharmaceutics.

Fahmuddin A., Sulaeman, Suprapto, Eviati, Prasetyo B.H., Djoko S., Ladiyani R. W ., Sri E.P ., Farida M., Didi S., dan Nuraini. 2005. Petunjuk Teknis Analisis Kimia Tanah, Tanaman, Air dan Pupuk. Balai Penelitian Tanah, Badan Penelitian dan Pengembangan Pertanian Departemen Pertanian.

Fatimah D. 2008. Efektivitas Penggunaan Asam Sitrat dalam Pembuatan Gelatin Tulang Ikan Bandeng(Chanos-Chanos furskal).[Skripsi].Malang: Jurusan Kimia, FakultasSains dan Teknologi, Universitaslslam Negeri Malang.

Garwan R. 2009. Perkembangan histamin selama proses fermentasi penyimpanan produk bekasang jeroan ikan cakalang (Katsuwonus pelamis). Skripsi Bogor. Fakultas IImu Perikanan dan Kelautan, Institut Pertanian Bogor.

Gelatin Manufacture Institute Of America. (2012). GMIA.Gelatin Hanbook.http://www.Gelatin gmia.com/imag
es/GMIA Gelatin Manual 2012.Pdf. [5 Desember 2013].

GMIA. 2001. Raw Material and Production of Edible Gelatins.

(http/l:www.gelatin.gmai.com/gelatin/applicat ion/edible gelatin/ diakses 2 Maret 2019).

Gunawan F,Suptijah P dan Uju, 2017. Ekstraksi dan Karakterisasi Gelatin Kulit Ikan Tenggiri (Scomberomorus commersonii) dari Provinsi Kepulauan Bangka Belitung.Jurnal Pengolahan Hasil Perikanan Indonesia. 20(3): 568-581.

Iqbal M, Anam C dan Ridwan AA. 2015. Optimasi Rendemen dan Kekuatan Gel Gelatin Ekstrak Tulang Ikan Lele Dumbo (Clarias gariepinus sp.). Fakultas Pertanian, Universitas Sebelas Maret. Surakarta. Jurnal Teknosains Pangan 4 (empat).

Jones, N.R.1977. Uses of Gelatine in Edible Product, In : A.G. Ward, A. Courts (Ed), The Science and Technology of Gelatine. New York: Academic Press. New York, pp. 366-392.

Junianto dan Kiki H. 2006.Produksi Gelatin dari Tulang dan Pemanfaatannya sebagai bahan Dasar Pembuatan Cangkang Kapsul. Jurnal Penelitian Hibah Bersaing IV. Tahun 1.

KKP. 2015. Kelautan dan Perikanan Dalam Angka. Kementrian Kelautan dan Perikanan.

Mulyani T., Sudaryati dan Rahmawati SF. 2012. Hidrolisis Gelatin Tulang Ikan Kakap menggunakan Larutan Asam. Program Studi Teknologi Pan gan. FTIUPN“Veteran” Jatim. Surabaya (http :/lejournal.upnjatim.ac.id/index.php/rekapan gan/article/view/406).Diakses pada tanggal 17 april 2015.

Marsaid dan Atmaja L. 2011. Karakterisasi Sifat Kimia, Fisik dan Termal Ekstrak Gelatin Dari Tulang Ikan Tuna (Thunnus sp) pada Variasi Larutan Asam Untuk Perendaman. Seminar Nasional Kimia dan Pendidikan Kimia III. Program Studi Pendidikan Kimia Jurusan FKIP. Universitas Sebelah Maret Surakarta.

Nurmilah S, dan Siti. 2018. Ekstrak Gelatin Tulang Ikan Kakap (L. Macolor niger) Menggunakan Metode Asam. Fakultas Pendidikan 
Teknologi dan Kejuruan Universitas Pendidikan Indonesia. Riset Agroindustri.

Panjaitan, T.F.C., 2017. Optimasi ekstraksi gelatin dari tulang ikan tuna (Thunnus albacares).Jurnal Wiyata Penelitian Sains dan Kesehatan, 3(1): 11-16.

Pratama, Wulandari, Supriadi A., dan Purwanto B. 2013. Pengaruh Defatting dan Suhu Ekstraksi Terhadap Karakteristik Gelatin Tulang Ikan Gabus. Jurnal: Fishtech. Vol.2 No.1

Rahayu. 2008.2 Indikator. http://kimia.upi/utama/bahanajar/kuliah/indik ator.html. [diakses pada 18 juli 2019]

Santoso C, Surti T, dan Sumardianto. 2015. Perbedaan Penggunaan Konsentrasi Larutan Asam Sitrat Dalam Pembuatan Gelatin Tulang Rawan Ikan pari Mondol (Himantura gerrardi). Universitas diponegoro, Semarang.Jurnal Pengolahan dan Bioteknologi Hasil Perikanan, Volume 4.Nomor 2.

Sartika, D. 2009. Pengembangan Produk Marshmallow dari Gelatin Kulit Ikan Kakap Merah (Lutjanus sp.).SKRIPSI.Institut Pertanian Bogor. Bogor.

Sasmitaloka, K. S, Miskiyah dan Juniawati 2017. Kajian Potensi Kulit Sapi Kering Sebagai Bahan Dasar Produksi Gelatin Halal.

SNI 06-3735. 1995. Mutu dan Cara Uji Gelatin. Dewan Standarnisasi Nasional. Jakarta.

Tazwir. 2007. Optimasi Pembuatan Gelatin dari Tulang Ikan Kaci-Kaci (Plectorhynchus chaetodonoides Lac.)Menggunakan Berbagai Konsentrasi Asam dan Waktu Ekstraksi.Jurnal Pascapanen dan Bioteknologi Kelautan dan Perikanan. Volume 2 No. 1.

Trilaksani W., Mala N., dan Ima H. S. 2012. Ekstraksi gelatin kulit ikan kakap merah (Lutjanus sp.) dengan proses perlakuan asam. Institut Pertanian Bogor. JPHPI 2012 Volume 105 No.3..

Ulfah M. 2011. Pengaruh Konsentrasi Larutan Asam Asetat dan Lama Waktu Perendaman Terhadap Sifat-Sifat GelatinCeker Ayam. J Agritech 31 (3): 161-167.

Wicaksono AS, 2017. Pemanfaatan Limbah Tulang Ikan Tongkol (Euthynnus affinis) sebagai Gelatin (Studi Konsentrasi Asam Khlorida dan Waktu Perendaman).[Skripsi].Jurusan IImu dan Teknologi Pangan, Universitas Muhamadiayah Malang. Malang.

Wiraatmaja, H. 2006. Perbaikan Nilai Tambah Limbah Tulang Ikan Tuna (Thunnus sp.)Menjadi Gelatin serta Analisis Sifat fisikoKimia (Skripsi). Institut Pertanian Bogor, Bogor 